\title{
Insulin-Like Growth Factor 1 and a Cytosolic Tyrosine Kinase Activate Chloride Outward Transport during Maturation of Hippocampal Neurons
}

\author{
Wolfgang Kelsch, ${ }^{1}$ Sheriar Hormuzdi, ${ }^{2}$ Emine Straube, ${ }^{1}$ Andrea Lewen, ${ }^{1}$ Hannah Monyer, ${ }^{2}$ and \\ Ulrich Misgeld 1 \\ 1/nstitut für Physiologie und Pathophysiologie and 2Institut für Klinische Neurobiologie, Interdisziplinäres Zentrum für \\ Neurowissenschaften, Universität Heidelberg, D-69120 Heidelberg, Germany
}

The development of hyperpolarizing inhibition is an important step in the maturation of neuronal networks. Hyperpolarizing inhibition requires $\mathrm{Cl}^{-}$outward transport that is accomplished by $\mathrm{KCC} 2$, a $\mathrm{K}^{+} / \mathrm{Cl}^{-}$cotransporter. We show that cultured hippocampal neurons initially contain an inactive form of the KCC2 protein, which becomes activated during subsequent maturation of the neurons. We also show that this process is accelerated by transient stimulation of IGF-1 receptors. Because the transporter can be rapidly activated by coapplication of IGF-1 and an Src kinase and can be deactivated by membrane-permeable protein tyrosine kinase inhibitors, we suggest that activation of $\mathrm{K}^{+} / \mathrm{Cl}^{-}$cotransporter function by endogenous protein tyrosine kinases mediates the developmental switch of GABAergic responses to hyperpolarizing inhibition.

Key words: development; furosemide; $G A B A_{A}$; genistein; hippocampus; IGF-1; KCC2; tyrosine kinase
In the developing rat hippocampus, fast GABAergic transmission is depolarizing early in development and becomes hyperpolarizing and strictly inhibitory only by the end of the first postnatal week (Cherubini et al., 1991). The direction of $\mathrm{Cl}^{-}$currents flowing through $\mathrm{GABA}_{\mathrm{A}}$ receptors depends on the transmembranal gradient for $\mathrm{Cl}^{-}$currents. $\mathrm{Cl}^{-}$influx requires low levels of intracellular $\left[\mathrm{Cl}^{-}\right]$, which is achieved by extrusion of $\mathrm{Cl}^{-}$by a furosemide-sensitive transporter (Misgeld et al., 1986; Thompson et al., 1988; Jarolimek et al., 1999; Kakazu et al., 1999) whose driving force is determined by extracellular $\left[\mathrm{K}^{+}\right]$(Payne, 1997; Jarolimek et al., 1999). There is considerable evidence suggesting that the recently cloned neuronal $\mathrm{K}^{+} / \mathrm{Cl}^{-}$cotransporter, $\mathrm{KCC} 2$, accomplishes this transport (Payne et al., 1996). A reduction in the expression of $\mathrm{KCC} 2$ by antisense nucleotides was shown to decrease the driving force for hyperpolarizing GABA currents in hippocampal CA1 neurons (Rivera et al., 1999). KCC2 expression increases in forebrain regions during the first postnatal weeks (Clayton et al., 1998; Lu et al., 1999; Rivera et al., 1999). At approximately this time, $\mathrm{GABA}_{\mathrm{A}}$ and glycine receptor responses become hyperpolarizing (Ehrlich et al., 1999; Kakazu et al., 1999; Rivera et al., 1999; DeFazio et al., 2000), and giant depolarizing potentials that are blocked by $\mathrm{GABA}_{\mathrm{A}}$ receptor antagonists disappear in the hippocampus (Ben-Ari et al., 1989). That KCC2 is the dominant neuronal $\mathrm{Cl}^{-}$extruding molecule, is important for synaptic inhibition by GABA or glycine, and is supported by the

Received June 20, 2001; revised Aug. 8, 2001; accepted Aug. 14, 2001.

The study was supported by Deutsche Forschungsgemeinschaft Grant MI255/4-1 (U.M.), Sonderforschungsbereich 488 (H.M.), and the Schilling Foundation (H.M.). The excellent technical assistance of Ulla Amtmann is gratefully acknowledged. We are particularly grateful to Dr. J. A. Payne for the gift of antibody and Dr. K. Kaila for helpful discussions.

Correspondence should be addressed to Dr. Ulrich Misgeld, Institut für Physiologie und Pathophysiologie, Universität Heidelberg, Im Neuenheimer Feld 326, D-69120 Heidelberg, Germany. E-mail: ulrich.misgeld@pio1.uni-heidelberg.de. Copyright (C) 2001 Society for Neuroscience 0270-6474/01/218339-09\$15.00/0 abnormalities observed in the developing spinal cord and brainstem of KCC2 knock-out mice (Hübner et al., 2001).

Protein tyrosine kinase (PTK) phosphorylation is considered a key biochemical event in numerous cellular processes, including proliferation, growth, and differentiation, and has also been implicated in synaptogenesis (Catarsi and Drapeau, 1993). Protein tyrosine kinases are subdivided into the cytosolic nonreceptor family and the transmembrane growth factor receptor family, which includes receptors for insulin and insulin-like growth factor (IGF-1). The maturation of postsynaptic inhibition may require both a cytoplasmic PTK, which increases $\mathrm{GABA}_{\mathrm{A}}$ receptormediated currents (Moss et al., 1995), and insulin, which was shown to induce a rapid translocation of $\mathrm{GABA}_{\mathrm{A}}$ receptors from intracellular compartments to the plasma membrane (Wan et al., 1997b). KCC2 is also known to have a C-terminal PTK consensus site (Payne, 1997). Therefore, the maturation of postsynaptic inhibition may, in addition to other mechanisms, also involve the effects of PTK and insulin acting on KCC2.

Previously, we presented an assay that allows one to determine the direction of KCC2 transport as a function of extracellular $\mathrm{K}^{+}$ concentration (Jarolimek et al., 1999). A major advantage of the assay is that the driving force for the transporter is set by defined intracellular and extracellular ion concentrations and that $\mathrm{GABA}_{\mathrm{A}}$ currents are not confounded by the influence of $\mathrm{HCO}_{3}{ }^{-}$ ions (Kaila et al., 1993). In this study, we used the assay and show that PTK inhibitors reduce KCC2-mediated transport. Furthermore, we provide evidence that insulin and IGF-1 in conjunction with a cytosolic PTK, c-Src, rapidly activate KCC2.

\section{MATERIALS AND METHODS}

Cell culture. Pregnant Wistar rats were anesthetized with ether and killed by decapitation. The embryos were removed, placed in sterile, ice-cold Gey's buffered salt solution [containing (in $\mathrm{mM}$ ): $137 \mathrm{NaCl}, 5 \mathrm{KCl}, 0.3$ $\mathrm{MgSO}_{4}, 1 \mathrm{NaH}_{2} \mathrm{PO}_{4}, 1.5 \mathrm{CaCl}_{2}, 2.7 \mathrm{NaHCO}_{3}, 0.2 \mathrm{KH}_{2} \mathrm{PO}_{4}, 1 \mathrm{MgCl}_{2}$, and 5 glucose, at $\mathrm{pH}$ 7.4], and immediately decapitated. Hippocampal anlage from 14-d-old embryos was mechanically dissociated and plated on a 
primary culture of glial cells from the same area. Cell culture conditions were the same as described previously (Jarolimek and Misgeld, 1992). For the incubation experiments, neurons were raised in medium containing either bovine insulin ( $30 \mu \mathrm{g} / \mathrm{ml}$; Life Technologies, Paisley, UK) or IGF-1 (50 ng/ml; Sigma, Deisenhofen, Germany) from 2-5 or 2-8 d in culture (DIC), during which the medium was replaced two to three times. Afterward, half of the medium was exchanged twice per week with medium lacking insulin or IGF-1. Sister control cultures, raised in the absence of insulin, were obtained from the same embryos and recorded on the same days. Cultures raised with insulin contained considerably larger cell numbers than their counterparts (data not shown).

Electrophysiological recordings. Recordings were performed at room temperature $\left(22-25^{\circ} \mathrm{C}\right)$ in the whole-cell voltage-clamp configuration with a patch-clamp amplifier Axopatch 200 B (Axon Instruments, Foster City, CA). The composition of the extracellular solution was (in mM): $156 \mathrm{NaCl}, 1 \mathrm{CsCl}, 2 \mathrm{KCl}, 2 \mathrm{CaCl}_{2}, 1 \mathrm{MgCl}_{2}, 15$ glucose, and $10 \mathrm{HEPES}$, $\mathrm{pH}$ 7.3. Composition of the patch pipette solution was (in $\mathrm{mM}$ ): $3.5 \mathrm{NaCl}$, $5 \mathrm{KCl}, 130 \mathrm{~K}$-glucuronate, $0.25 \mathrm{CaCl}_{2}, 0.5 \mathrm{MgCl}_{2}, 10$ glucose, $10 \mathrm{HEPES}$, 5 5-N-(2,6-dimethylphenylcarbamoylmethyl)-triethylammonium bromide (QX314), and 0.1 or $2 \mathrm{Mg}$-ATP, pH 7.3. For a more detailed description of the assay, see Jarolimek et al. (1999). Extracellular solutions were applied by a multibarreled perfusion system that was positioned $\sim 250$ $\mu \mathrm{m}$ apart from the soma of the recorded cell. All experiments were performed with $10 \mu \mathrm{M}$ 6,7-dinitroquinoxaline-2,3-dione and $1 \mu \mathrm{M}$ DL-2amino-4-methyl-5-phosphono-3-pentenoic acid in the extracellular solution to block glutamatergic synaptic currents. The remaining currents could be completely blocked by application of $20 \mu \mathrm{M}$ bicuculline (Jarolimek et al., 1999). Drugs were from Sigma, except lavendustin A (Calbiochem, Schwalbach, Germany). Insulin or IGF-1 were added to the extracellular solution. c-Src (recombinant pp60 $0^{\mathrm{c}-\mathrm{Src}}$; Upstate Biotechnology, from Biomol, Hamburg, Germany) was added to the patch pipette solution directly before the experiment. For control experiments, c-Src was heat-inactivated at $60^{\circ} \mathrm{C}$ for $15 \mathrm{~min}$. For all experiments with acute application of insulin, IGF-1, and/or c-Src, patch pipette solution containing $2 \mathrm{~mm} \mathrm{Mg-ATP}$ was used.

Patch pipettes were fabricated from borosilicate glass (Hilgenberg, Malsfeld, Germany), and their resistances to bath ranged from 2.5 to 4.5 $\mathrm{M} \Omega$. The access resistance was estimated from the amplitude of the capacitive current evoked by a $5 \mathrm{mV}$ square pulse. Only access resistances between 10 and $20 \mathrm{M} \Omega$ were accepted and routinely checked during the recording. For a determination of the liquid junction potential between the patch pipette and the extracellular solution, see Jarolimek et al. (1999). All values were corrected by $-14 \mathrm{mV}$. Recordings were started $>5$ min after the whole-cell configuration was established to allow adequate time for QX314 to take effect and for anions to equilibrate. After $5 \mathrm{~min}$, no additional change in dendritic or somatic $E_{\mathrm{GABA}}$ was observed for the duration of recording (up to $2 \mathrm{hr}$ ). GABA (1 mM; Sigma) was applied by pressure ejection (1-20 kPa; 20-40 msec) every 15 sec from a pipette with a $<1 \mu \mathrm{m}$ opening. $I_{\mathrm{GABA}}$ was measured in the presence of TTX (0.3 $\mu \mathrm{M}$; Alomone Labs, Jerusalem, Israel) to avoid superposition of $I_{\mathrm{GABA}}$ and action potential-dependent spontaneous IPSCs (sIPSCs). Currents were recorded at holding potentials $\left(V_{\mathrm{H}}\right)$ near $E_{\mathrm{GABA}}$. After 15-45 sec at a new $V_{\mathrm{H}}$, the current amplitudes induced by three consecutive applications were averaged. Despite the rapid exchange of the extracellular solution $(\sim 0.5 \mathrm{sec})$ around the neuron, effects of drugs were determined $>1$ min after start of the application. During this time, $V_{\mathrm{H}}$ was set to $E_{\mathrm{GABA}}$. For the analysis of sIPSCs, we first determined the reversal potential, and, from the reversal potential, $V_{\mathrm{H}}$ was changed in small steps to determine the voltage dependence of synaptic currents.

Data analysis. Data were filtered at $1.3 \mathrm{kHz}$ with a four-pole Bessel filter and were acquired and analyzed with pClamp6 (Axon Instruments) and Igor Pro (WaveMetrics Inc., Eugene, OR). The amplitudes of sIPSCs were analyzed with a program written in our laboratory (Jarolimek and Misgeld, 1997). The reversal potential of $I_{\mathrm{GABA}}$ was determined by fitting the current-voltage plot by a linear regression $(r \geq 0.95)$. Somatic sIPSCs and all sIPSCs recorded in the presence of a blocker for cationanion transporters were fitted together only if $r \geq 0.75$. The 10 largest inwardly and outwardly directed sIPSCs, respectively, were averaged for each data point of the current-voltage relationship. Statistic analysis of data are reported as mean \pm SEM.

Reverse transcription-PCR. To evaluate levels of KCC2 mRNA in neurons, a semiquantitative reverse transcription (RT)-PCR approach was undertaken in which fragments corresponding to the KCC2 and the internal standard, neurofilament light chain (NFL) (Moshnyakov et al.,
1996), transcripts were coamplified. The specificity of the reaction conditions was determined by amplifying the cDNA with either the KCC2 or NFL primer pair (see below) individually and then sequencing the reaction products. Fragments corresponding to the KCC2 and NFL transcripts so amplified were purified and ${ }^{32} \mathrm{P}$-dCTP labeled to generate specific probes for the Southern blot analysis (see below). Conditions for the cDNA synthesis and PCR (given below) were chosen such that the reaction products were hardly visible after 20 amplification cycles but were abundant after 30 cycles (see Fig. 6C1). Because the reaction products were well within the exponential phase of the PCR, all quantitations were done on reaction products amplified for only 20 cycles. Reaction products were electrophoresed on a $2 \%$ agarose gel, subjected to Southern blot analysis, and quantified with a bio-imaging analyzer (FUJIX BAS1000; Fujifilm, Tokyo, Japan). To maximize accuracy, the same blots were stripped and then probed individually with either KCC2or NFL-labeled fragments (see Fig. 6C2). After correcting for the amount of NFL amplified, the relative levels of KCC2 expressed by neurons after treatment with insulin to sister controls was determined for three independent experiments and expressed as a ratio (see Fig. 6D). For each cDNA, the amplifications, Southern blots, and quantitations were repeated four times.

cDNA reactions were conducted on RNA prepared from sister control and insulin-treated cultures, using Moloney murine leukemia virus reverse transcriptase and random hexanucleotide primers, and had a final volume of $30 \mu \mathrm{l}$. For PCR reactions, $0.5 \mu \mathrm{l}$ of the cDNA reaction was used along with $0.5 \mu \mathrm{M}$ of each of the four primers (given below), 0.25 mM of each dNTP, $10 \mu \mathrm{l}$ of $10 \times$ buffer, $0.5 \mu \mathrm{l}$ of Taq polymerase, and 1 $\mathrm{mM} \mathrm{MgCl}_{2}$. The following primers were used: 5'-GCAGCCCCTTCATCAACAGCAC-3' and '5'-CATCGCTGGGAAGAGGTAAGC-3', which amplified a $559 \mathrm{bp}$ fragment of the KCC2 transcript, and $5^{\prime}$ TGCACGAGGAAGAGATCGCCGAGCT-3' and 5'-CTGTAAGCTGCAATCTCAATGT-3', which amplified a 495 bp fragment of the NFL transcript.

Immunocytochemistry. The abundance of $\mathrm{KCC} 2$ protein in neurons treated with insulin and in untreated controls was visualized with an antibody whose specificity and utility has been described previously (Williams et al., 1999). Neurons cultured on coverslips were fixed for 10 min at room temperature with $4 \%$ paraformaldehyde prepared in PBS. After brief washes with PBS, they were permeabilized by incubation for 5 min at room temperature in a $0.2 \%$ Triton X-100 (Tr)-PBS solution, rinsed again with PBS, and then incubated in a solution containing $0.2 \%$ Tr and $4 \%$ goat serum (GS)-PBS for $30 \mathrm{~min}$ at room temperature. The coverslips were incubated in the primary antibody (1:200 dilution; $0.1 \%$ $\mathrm{Tr}$ and $2 \%$ GS-PBS) overnight at $4^{\circ} \mathrm{C}$. After rinses in $1 \%$ GS-PBS, the FITC-conjugated anti-rabbit secondary antibody was added (1:200 dilution; Jackson ImmunoResearch, West Grove, PA), and the coverslips were incubated for $2 \mathrm{hr}$ at room temperature. The coverslips were then rinsed, mounted on slides, visualized, and photographed with an Axio Plan 2 microscope (Zeiss, Oberkochen, Germany).

\section{RESULTS}

\section{KCC2 activity distinguishes between two types of neurons}

Whole-cell recordings from embryonic (E14) hippocampal neurons 27-31 DIC were performed under conditions of $15 \mathrm{~mm}$ (10 $\mathrm{mM} \mathrm{Cl}^{-}$and $5 \mathrm{~mm} \mathrm{Br}^{-}$) (cf. Jarolimek et al., 1999) permeant anions in the patch pipette and $2 \mathrm{mM} \mathrm{K}^{+}$in the extracellular solution $\left(\left[\mathrm{K}^{+}\right]_{\text {extra }}\right)$. Only cells with membrane potentials more negative than $-55 \mathrm{mV}$ were included in the analysis. We applied GABA (1 mM) focally to either the soma or a dendrite of a single cell. The distance between the somatic and dendritic applications was at least $100 \mu \mathrm{m}$. Responses to GABA applications allowed us to discriminate two types of cells, which we termed type 1 and type 2 . In type 1 neurons, the reversal potential $\left(E_{\mathrm{GABA}}\right)$ for dendritic currents was more negative than $E_{\mathrm{GABA}}$ for currents induced by somatic applications $(-81.3 \pm 2.9$ and $-59.5 \pm 1.6$ $\mathrm{mV}$, respectively; $p \leq 0.001 ; n=4)$. Furosemide $(100 \mu \mathrm{M})$ changed the driving force of the currents induced by focal dendritic applications (Fig. 1A1). Plots of current amplitudes versus holding potential $\left(V_{\mathrm{H}}\right)$ revealed a positive shift of dendritic $E_{\mathrm{GABA}}$ in the presence of furosemide (Fig. 1A2). In the same 


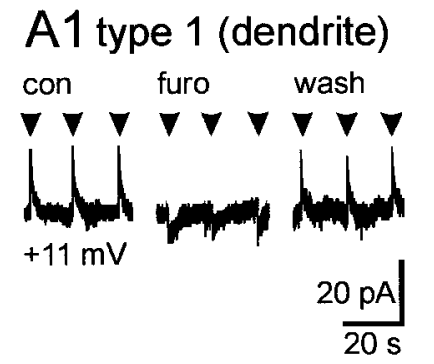

A2 dendrite

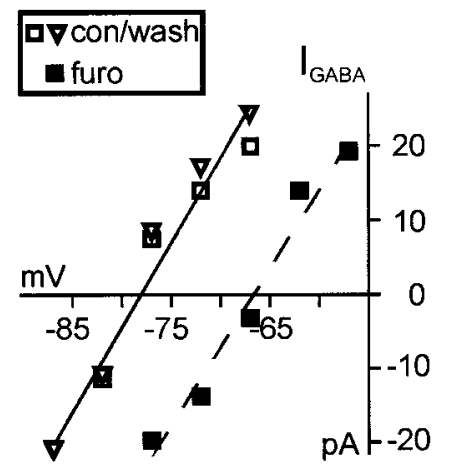

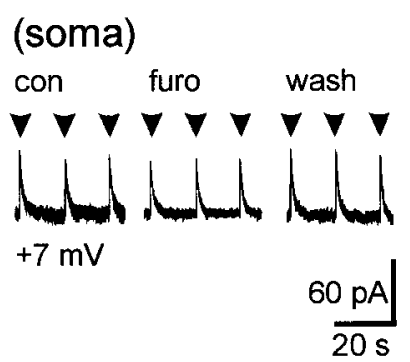

B type 2

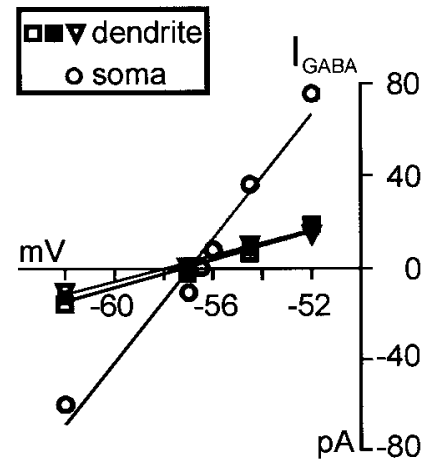

Figure 1. Somatodendritic gradient for $E_{\mathrm{GABA}}$ in type 1 but not type 2 neurons. $A$, Focal application of GABA $(1 \mathrm{~mm})$ to a type 1 neuron. $A 1$, Furosemide $(100 \mu \mathrm{M})$ reversed the direction of GABA currents at the dendrite but not at the soma of the same cell. Below the traces, the driving force $\left(V_{\mathrm{H}}-E_{\mathrm{GABA}}\right)$ is indicated. Somatic $E_{\mathrm{GABA}}$ was $-64 \mathrm{mV}$, and dendritic $E_{\mathrm{GABA}}$ was $-78 \mathrm{mV}$. con, Control; furo, furosemide; wash, washout. $A 2$, Plots of GABA current amplitudes versus $V_{\mathrm{H}}$ revealed a positive shift of dendritic $E_{\mathrm{GABA}}$ in furosemide (100 $\mu \mathrm{M}$; $\left.\square\right)$ compared with control ( $\square$ ) and washout $(\nabla)$. $B$, Focal application of GABA $(1 \mathrm{~mm})$ to a type 2 neuron. There was no difference between $E_{\mathrm{GABA}}$ in the dendrite $(\square)$ and in the soma $(\bigcirc)$ of the same cell. Furosemide $(100 \mu \mathrm{M}$; $\mathbf{\square})$ did not alter $E_{\mathrm{GABA}}$ of dendritic currents. Control, $\square$; washout, $\nabla$.

cells, currents induced by focal somatic applications were not altered (Fig. 1A1). In type 2 neurons (Fig. $1 B$ ), on the other hand, there was no difference between $E_{\mathrm{GABA}}$ obtained with either dendritic or somatic applications $(-57 \pm 0$ and $-56 \pm 1.3 \mathrm{mV}$, respectively; $n=4$ ), and furosemide had no effect on $E_{\mathrm{GABA}}$ for dendritic currents.

Pharmacological blockade of ionotropic glutamate receptors allowed us to measure sIPSCs mediated by $\mathrm{GABA}_{\mathrm{A}}$ receptors. Cells exhibiting little spontaneous synaptic activity were not considered in this study. In half of the hippocampal neurons (type 1), the simultaneous occurrence of inward and outward sIPSCs (Fig. 2A1) prevented the determination of a single reversal potential $\left(E_{\text {rev }}\right)$. The other half (type 2) was characterized by sIPSCs that were either outward or inward depending on the respective $V_{\mathrm{H}}$ (Fig. 2B1). Only in type 1 neurons was it possible to alter the driving force for sIPSCs with the cation-anion transport blocker furosemide.

Figure $2 A 1$ shows a type 1 hippocampal neuron. Application of furosemide $(100 \mu \mathrm{M})$ reversed the direction of synaptic currents in $<1 \mathrm{~min}$. This effect was reversible during washout of furosemide. When amplitudes of the sIPSCs of this neuron were measured at varying $V_{\mathrm{H}}(-69$ to $-85 \mathrm{mV})$, the data points could be fitted by two linear regression lines (Fig. 2A2), and two different reversal potentials could be extrapolated. According to results obtained with focal GABA applications, data points yield-

A1 type 1

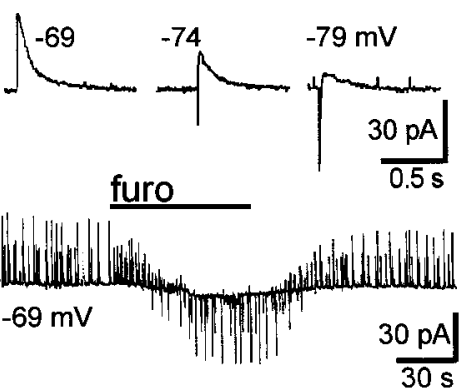

A2
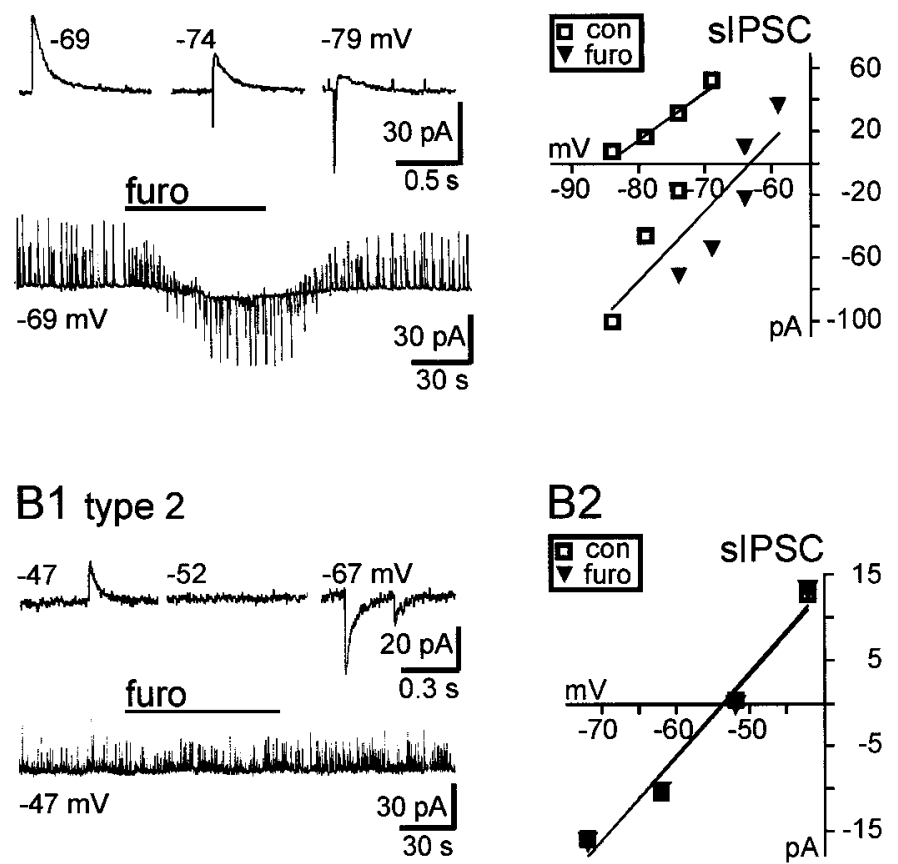

Figure 2. Comparison of furosemide effects on spontaneous IPSCs in type 1 and type 2 neurons. $A 1$, Simultaneous outward and inward sI PSCs characterize type 1 neurons. Application of furosemide $(100 \mu \mathrm{M})$ reversed the direction of sIPSCs. $A 2$, In the same neuron, dendritic and somatic sIPSCs could be fitted separately by linear regression lines ( $\square$ ). In furosemide $(100 \mu \mathrm{M})$, all sI PSCs could be fitted with the somatic regression line ( $\mathbf{\nabla})$. B1, B2, Type 2 neuron. Measurement of sIPSCs at varying $V_{\mathrm{H}}$ allowed to determine a reversal potential by linear regression $(r>$ $0.95 ; \square)$, and furosemide (100 $\mu \mathrm{M} ; \boldsymbol{\nabla})$ had no effect. Con, Control; furo, furosemide.

ing the more negative reversal potential are from dendritic sIPSCs. The other line connected values for somatic sIPSCs. Data points obtained in the presence of the transport blocker furosemide could be fitted with the somatic currents (Fig. 2A2). In contrast, for a type 2 neuron (Fig. $2 B$ ), measurement of sIPSC amplitudes at varying $V_{\mathbf{H}}$ allowed determination of a single reversal potential. In this cell, furosemide had no effect.

According to the data reported above, in type 1 neurons, dendritic sIPSCs can be discriminated from somatic sIPSCs by their respective driving forces. Driving forces for dendritic sIPSCs approached those of somatic sIPSCs during blockade of $\mathrm{Cl}^{-}$ transport by furosemide. Bumetanide mimicked the effects of furosemide (Fig. $3 A$ ) but was somewhat less effective than furosemide. At high concentration $(100 \mu \mathrm{M})$, bumetanide as well as furosemide reversed the direction of sIPSCs $(n=3)$ (Fig. $3 A)$. At low concentration, bumetanide $(25 \mu \mathrm{M})$ had no effect on spontaneous synaptic currents, whereas application of $25 \mu \mathrm{M}$ furosemide to the same type 1 neuron increased the amplitude of inward sIPSCs and decreased those of outward sIPSCs $(n=4)$. The stilbene derivative 4,4'-diisothiocyanatostilbene-2,2'-disulfonic acid (DIDS) was more effective than furosemide, but recovery was not always complete (Fig. $3 B, C$ ). These pharmacological characteristics match those of KCC2 expressed in human embryonic kidney cells (Payne, 1997).

The data indicated that a $\mathrm{Cl}^{-}$gradient exists between soma and dendrites of type 1 neurons, because $\mathrm{Cl}^{-}$transport exceeds the $\mathrm{Cl}^{-}$load provided by the patch pipette solution in the 
A bume
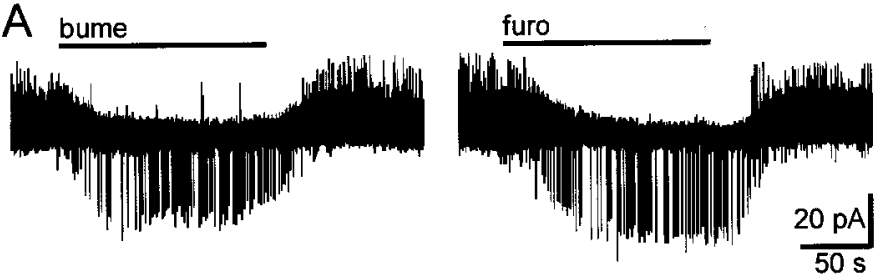

B

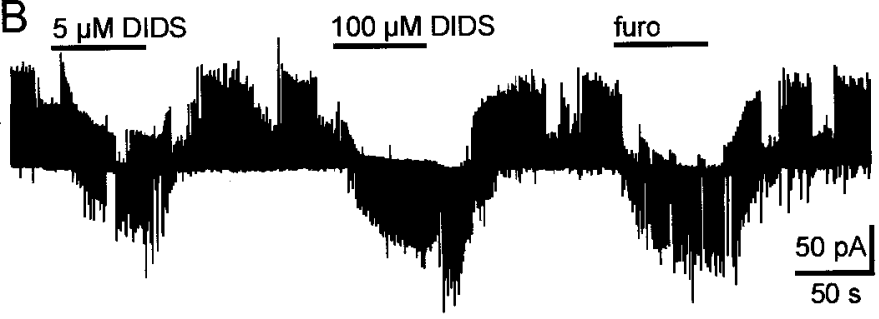

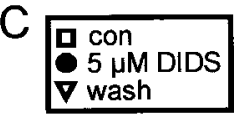

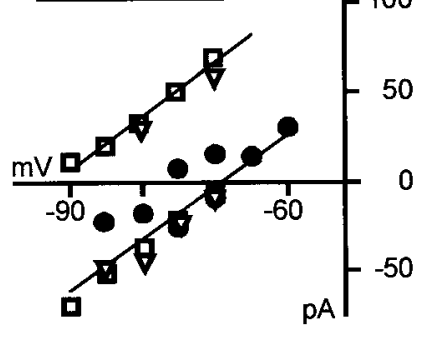

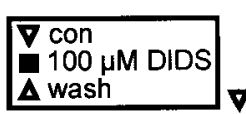

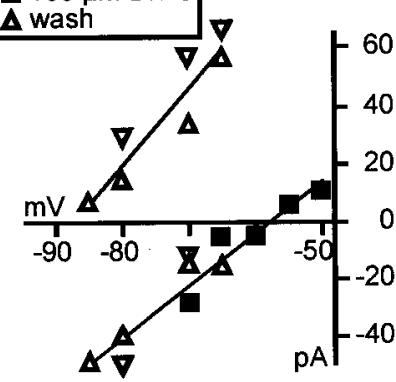

Figure 3. Pharmacological blockade of $\mathrm{Cl}^{-}$outward transport in type 1 neurons. $A$, Bumetanide $(100 \mu \mathrm{M})$ and furosemide $(100 \mu \mathrm{M})$ comparably reversed the direction of sIPSCs in the same neuron. $B$, Another blocker, DIDS, mimicked the effect of furosemide in a concentration-dependent manner, although, at high concentrations, the drug is known to block $\mathrm{Cl}^{-}$ channels as well as $\mathrm{Cl}^{-}$transport. $C$, Plots of amplitudes of sI PSCs versus $V_{\mathrm{H}}$ show that, in $100 \mu \mathrm{M}$ DIDS, all values for sIPSCs could be fitted together with the values for somatic sIPSCs in control. bume, Bumetanide; con, control; furo, furosemide; wash, washout.

dendrites of the neurons (Jarolimek et al., 1999). In contrast, type 2 neurons possess a uniform distribution of intracellular $\left[\mathrm{Cl}^{-}\right]$, because they lack net outward $\mathrm{Cl}^{-}$transport activity. These findings are summarized in Figure 4. In type 1 neurons (Fig. 4A1), $E_{\mathrm{GABA}}$ for dendritic GABA currents shifted to positive values in furosemide $\left(\Delta V_{\text {rev }}\right)$ (Fig. 4A2). For the quantification of furosemide effects on SIPSCs, we measured $V_{\mathrm{H}}$ at which the first outward sIPSCs with amplitudes twice the noise appeared. Furosemide induced a significant positive shift in this value (Fig. $4 A 3)$. In type 2 neurons, in which dendritic and somatic $E_{\mathrm{GABA}}$ were the same (Fig. 4B1), furosemide had no effect on dendritic $E_{\mathrm{GABA}}$ (Fig. $4 B 2$ ). $V_{\mathrm{H}}$ at which the first outward sIPSCs appeared was also not changed (Fig. 4B3). In conclusion, a furosemide-sensitive KCC generates the somatodendritic $\left[\mathrm{Cl}^{-}\right]$ gradient in type 1 neurons, whereas in type 2 neurons $\mathrm{KCC}$ activity is absent.

\section{Outward transport of chloride requires tyrosine kinase activity}

Neuron-specific KCC2 differs from the widely expressed $\mathrm{KCC} 1$ in a PTK consensus site (Payne, 1997). Hence, we tested the effect of PTK inhibitors on $\mathrm{Cl}^{-}$outward transport in type 1 neurons. Perfusion of lavendustin A $(10 \mu \mathrm{M})$, a membrane-permeable
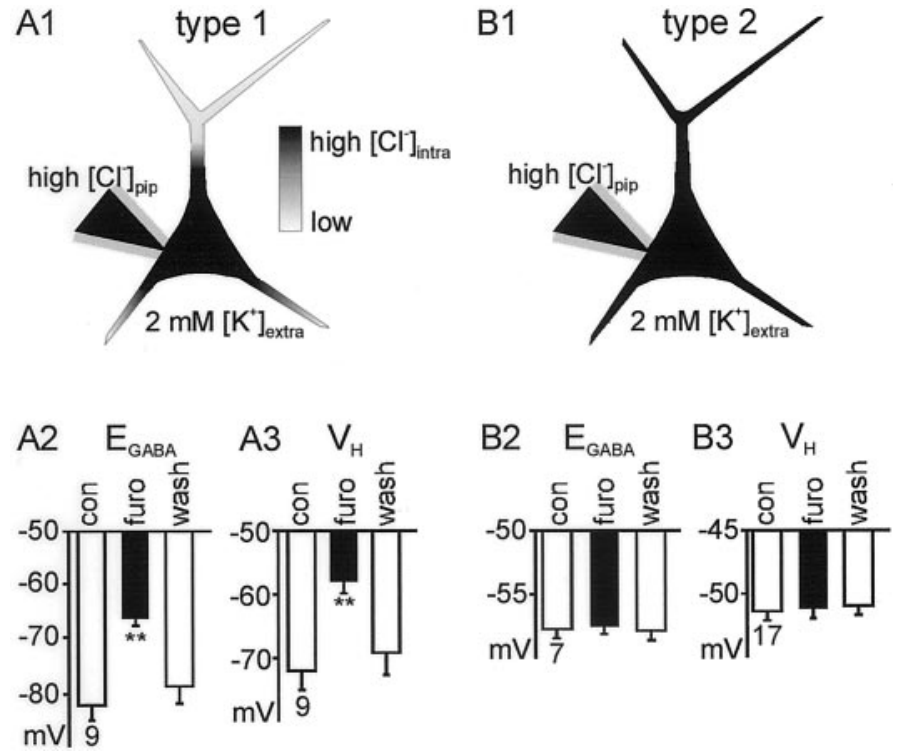

Figure 4. Somatic and dendritic $\left[\mathrm{Cl}^{-}\right]$in type 1 and type 2 neurons. $A 1$, Schematic drawing of a type 1 neuron. Net $\mathrm{Cl}^{-}$outward transport lowers intracellular $\left[\mathrm{Cl}^{-}\right]$in dendritic regions compared with the soma, which is loaded with $\left[\mathrm{Cl}^{-}\right]$by the patch pipette solution. $A 2, E_{\mathrm{GABA}}$ was determined for currents induced by focal application of GABA $(1 \mu \mathrm{M})$ to the dendrite of type 1 neurons; furosemide $(100 \mu \mathrm{M})$ reversibly shifted $E_{\mathrm{GABA}}$ to more positive potentials $(p \leq 0.001)$. $A 3$, Furosemide $(100 \mu \mathrm{M})$ induced shifts in the $V_{\mathrm{H}}$ to more positive potentials $(p \leq 0.01)$ at which the first sIPSCs with amplitudes twice the noise appeared. $B 1$ displays a type 2 neuron with an even $\left[\mathrm{Cl}^{-}\right]$in the dendrites and in the soma. $B 2$ displays focal applications of GABA $(1 \mathrm{~mm})$ to dendrites of type 2 neurons. No shift in $E_{\mathrm{GABA}}$ occurred when furosemide $(100 \mu \mathrm{M})$ was applied. B3, Same as $A 3$ for type 2 neurons, but there was no effect of furosemide (100 $\mu \mathrm{M})$. con, Control; furo, furosemide; wash, washout.

inhibitor of PTK (O'Dell et al., 1991), like furosemide, resulted in an increase of inward and a decrease of outward sIPSCs that was fully reversible only after a single application (Fig. 5A). This treatment also resulted in a decrease in the frequency of sIPSCs. To quantify the effect of lavendustin A (11 applications to five cells), we determined the amplitude ratio of outward to inward sIPSCs, which was strongly reduced during the application $(0.51 \pm 0.07 ; p \leq 0.001)$ (Fig. $5 B)$. Control experiments were performed using type 2 neurons because these cells have no KCC2-mediated transporter activity. Lavendustin A was applied at different $V_{\mathrm{H}}$, and the resultant sIPSCs were measured (17 applications to seven type 2 neurons). Under these conditions, the frequency and amplitudes of inward $(0.58 \pm 0.12)$ and outward sIPSCs $(0.6 \pm 0.08)$ normalized to control were reduced (Fig. $5 C$ ), but their ratio did not change.

Another membrane-permeable inhibitor of PTK, genistein (50 $\mu \mathrm{M})$ (Akiyama et al., 1987), produced a reversible decrease (13 applications to nine cells) in the amplitude ratio of outward to inward sIPSCs $(0.25 \pm 0.06 ; p \leq 0.001)$ in type 1 neurons (Fig. $5 B)$. In contrast, daidzein $(50 \mu \mathrm{M})$, the inactive analog of genistein (Akiyama et al., 1987), when applied to neurons that responded to genistein (six applications to four cells), had no effect on the ratio of outward to inward currents $(1.2 \pm 0.14)$ (Fig. $5 B$ ). In type 2 neurons (18 applications to three cells), genistein did not reduce the mean amplitude of either outward (0.99 \pm $0.08)$ or inward (0.84 \pm 0.13$)$ sIPSCs (Fig. $5 C$ ).

To circumvent effects of PTK inhibitors on spontaneous activ- 
A

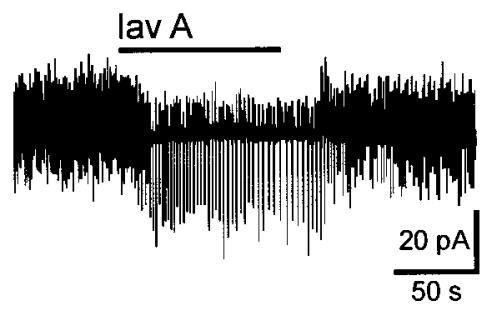

B type 1
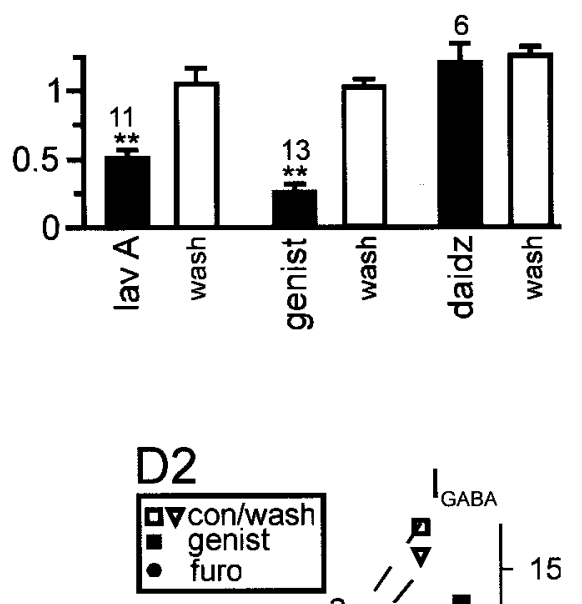

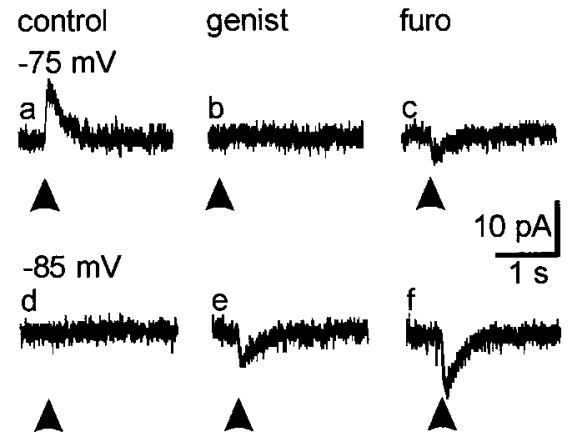

furo
C type 2
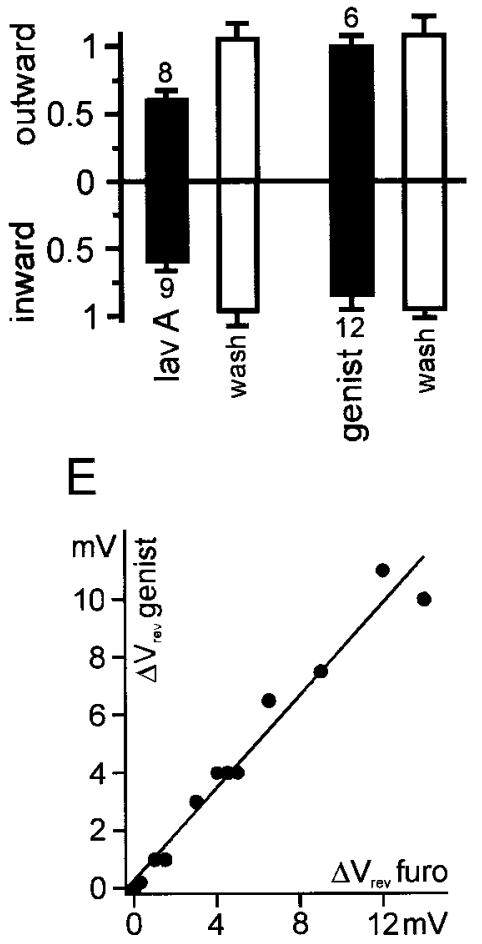

Figure 5. Reduction of $\mathrm{Cl}^{-}$outward transport by inhibitors of PTK. $A$, In a type 1 neuron, lavendustin A (10 $\left.\mu \mathrm{M}\right)$ had an effect on sIPSCs comparable with furosemide. $B$, The ratio of outward to inward sIPSCs normalized to control was significantly reduced during application of lavendustin A (10 $\mu \mathrm{M}$; $p \leq 0.001)$ or genistein $(50 \mu \mathrm{M}$ for $30 \mathrm{sec} ; p \leq 0.001)$ but not by daidzein $(50 \mu \mathrm{M}$ for $30 \mathrm{sec})$, the inactive analog of genistein. $C$, In type 2 neurons, inward currents and outward currents normalized to control at the respective $V_{\mathrm{H}}$ were reduced, but the ratio did not change. $D 1$, Currents induced by focal applications of GABA $(1 \mathrm{mM})$ to a dendrite decreased or reversed in direction, respectively, when genistein $(50 \mu \mathrm{M})$ or furosemide $(100 \mu \mathrm{M})$ were applied to a type 1 neuron $\left(V_{\mathrm{H}}\right.$ of $\left.-75 \mathrm{mV}\right)$. At $E_{\mathrm{GABA}}\left(V_{\mathrm{H}}\right.$ of $\left.-85 \mathrm{mV}\right)$, there was an increase in inward currents in genistein and furosemide. $D 2$, The current-voltage relationship for the neuron shown in $D 1$ revealed a positive shift in $E_{\mathrm{GABA}}\left(\Delta V_{\mathrm{rev}}\right)$ in genistein (ם) and furosemide $(\bullet)$. Control, $\square$; washout, $\nabla . E$, Correlation of $\Delta V_{\text {rev }}$ induced by genistein $(50 \mu \mathrm{M})$ and furosemide $(100 \mu \mathrm{M})$ in 12 neurons was highly significant $(r=0.98)$. con, Control; daidz, daidzein; furo, furosemide; genist, genistein; lav A, lavendustin $\mathrm{A}$; wash, washout.

ity, we applied GABA focally to dendrites of type 1 neurons and measured $\Delta V_{\text {rev }}$ for GABA currents. Genistein shifted $E_{\mathrm{GABA}}$ to positive values $\left(\Delta V_{\text {rev }}\right.$ was $\left.+7.5 \pm 1.1 \mathrm{mV} ; n=10\right)$ and caused a new steady state, which was reached within 3 min after application and was reversible in most instances. Genistein, however, had no effect on $E_{\mathrm{GABA}}$ if GABA was applied to the soma of cells $(n=3)$ because somatic $\left[\mathrm{Cl}^{-}\right]_{\text {intra }}$ is determined by the $\mathrm{Cl}^{-}$load through the patch pipette. We next compared $\Delta V_{\text {rev }}$ induced by genistein or furosemide if they were applied to the same type 1 or type 2 cell $(n=12)$. As shown in Figure 5, D1 and D2, a given cell responded with almost the same $\Delta V_{\text {rev }}$ to either genistein or furosemide. The correlation of $\Delta V_{\text {rev }}$ induced by genistein or furosemide was highly significant $(r=0.98)$, strongly suggesting that both drugs acted by blocking the same pathway (Fig. $5 E$ ). Furthermore, the slope of the curve revealed that the genistein effect amounted to $80 \%$ of the furosemide effect.

Neuronal chloride channels, $\mathrm{ClC}-3$ and $\mathrm{ClC}-2$, are known to be activated or blocked by activators of protein kinase $\mathrm{A}$ and protein kinase C, respectively (Smith et al., 1995). Therefore, we applied forskolin, an activator of adenylylcyclase, $(20 \mu \mathrm{M} ; n=5)$, and phorbol-12-mystirate-13-acetate, an activator of protein kinase $\mathrm{C}$ $(1 \mu \mathrm{M} ; n=3)$, to the bath solution. None of them had an effect on the $\mathrm{Cl}^{-}$gradient and furosemide sensitivity (data not shown), although spontaneous synaptic activity increased as described previously (Capogna et al., 1995).

\section{Developmental activation of outward chloride transport}

We determined the developmental onset of type 1 neurons in cultures derived from hippocampus. There were time points when either type 1 or type 2 neurons predominated and a transitory period wherein both types existed. Type 1 neurons were the predominant cell type only after 35-44 DIC (26 of 29 cells), whereas type 2 predominated up to 23 DIC (18 of 19 cells). The time of appearance of type 1 neurons could be shortened by incubation with a growth factor that activates PTK. In hippocampal cultures raised in insulin $(30 \mu \mathrm{g} / \mathrm{ml})$, type 1 neurons predominated as early as $21-24$ DIC (17 of 18 cells). In contrast, very few type 1 neurons ( 1 of 12 cells) were found in sister cultures raised without insulin (Fig. 6A). The same results were obtained with physiological concentrations of IGF-1 $(50 \mathrm{ng} / \mathrm{ml})$.

To determine whether the difference in $\mathrm{Cl}^{-}$transport between the two groups of neurons was attributable to differential expression of KCC2, we amplified KCC2 transcript by single-cell RTPCR from individual type 1 and type 2 neurons. Single-cell RT-PCR revealed no difference because 15 of 18 type 1 neurons and 10 of 15 type 2 neurons contained KCC2 mRNA (data not shown). To quantify the relative expression of KCC2 transcript in type 1 and type 2 neurons, we determined the abundance of KCC2 mRNA in 21-24 DIC cultures treated with insulin and in 

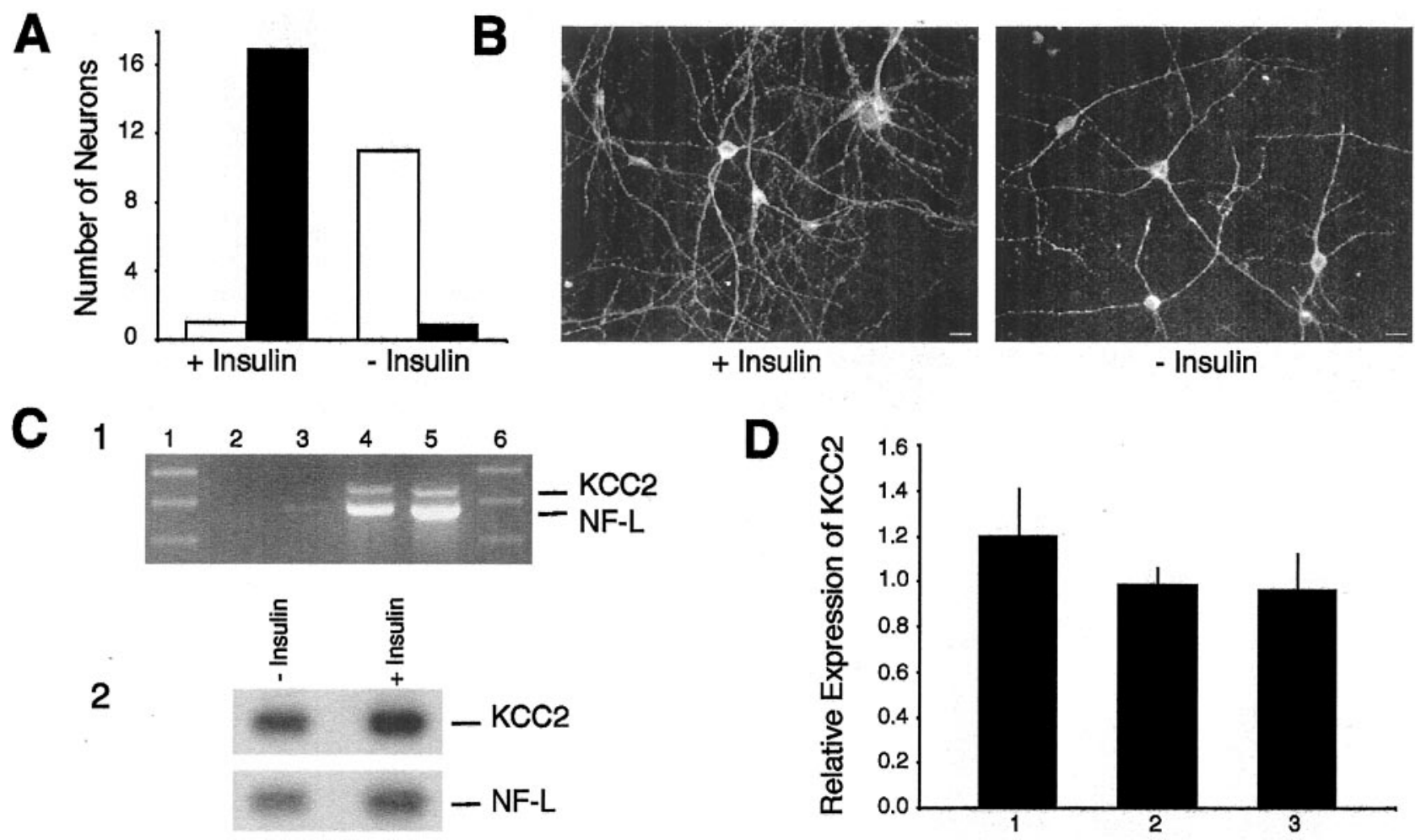

Figure 6. Abundance of type 1 neurons, but not expression of KCC 2 mRNA and protein, is enhanced by insulin. $A$, The relative number of type 1 neurons (black bars) is increased when hippocampal cell cultures are incubated in insulin, whereas type 2 neurons (white bars) predominate in untreated cultures. $B, \mathrm{KCC} 2$ protein is abundant in all neurons, regardless of insulin pretreatment. $C 1$, An ethidium bromide-stained agarose gel demonstrating the relative abundance of the coamplified KCC2 and NFL fragments after 10, 20, 30, or 40 (lanes 2-5, respectively; the 636, 517, and 396 bp DNA size markers are visible in lanes 1 and 6 ) amplification cycles. $C 2$, A representative Southern blot result illustrating the relative abundance of the KCC2 and NFL DNA fragments in insulin-treated and untreated samples. $D$, The relative abundance of KCC2 expression in insulin-treated samples expressed as a ratio of the amount of KCC2 amplified in insulin-treated samples to the amount in untreated samples. The results from three separate experiments $(n=4)$ indicate that the ratio did not deviate significantly from 1.0, suggesting that KCC2 expression was unaltered by insulin treatment.

sister control cultures. Semiquantitative RT-PCR, wherein KCC2 mRNA was amplified and normalized to the expression of NFL, indicated that both cultures expressed comparable amounts of KCC2 (Fig. 6D). In addition, immunocytochemical visualization of $\mathrm{KCC} 2$ protein revealed that it was abundant in both types of cultures (Fig. 6B). Thus, we concluded that the onset of transporter activity cannot be correlated with the amount of mRNA or with the mere presence of KCC2 protein.

The data presented above suggested that neurons with passive $E_{\mathrm{Cl}^{-}}$as well as neurons with functional transport contained KCC2 protein. Furthermore, PTK appeared to play a major role in regulating the transport. To test whether PTK could activate the transport, we applied insulin $(30 \mu \mathrm{g} / \mathrm{ml})$ in the bath for at least 30 min. This had no effect on its own $(n=3)$. However, if the application of insulin $(30 \mu \mathrm{g} / \mathrm{ml} ; n=7)$ or IGF-1 $(50-100 \mathrm{ng} / \mathrm{ml}$; $n=3$ ) was combined with the perfusion (15 min before application of insulin or IGF-1) of a cytoplasmic PTK (c-Src, $60 \mathrm{U} / \mathrm{ml}$ ) via the recording pipette, type 2 cells could acquire type 1 activity within 5 min (Fig. 7). The change manifested itself in the appearance of inward and outward sIPSCs at a holding potential, at which the cell had shown previously inward currents only (Fig. $7 B$ ). The application of c-Src alone (30 or $60 \mathrm{U} / \mathrm{ml}$ for $30 \mathrm{~min}$ ) was not effective $(n=6)$. Furthermore, whereas the cells recorded with c-Src did not respond to furosemide, furosemide induced a shift in the driving force for sIPSCs in the same cells after insulin or IGF-1 application $(n=9)$ (Fig. $7 B)$. To confirm that active tyrosine kinase was required for the change from type 2 to type
1 characteristics, we used heat-inactivated c-Src, which was unable to support the insulin effect $(n=3)$.

\section{DISCUSSION}

\section{KCC2-mediated outward transport of chloride}

In a previous study (Jarolimek et al., 1999), we demonstrated that a furosemide-sensitive $\mathrm{K}^{+} / \mathrm{Cl}^{-}$cotransporter generates a pronounced somatodendritic $\left[\mathrm{Cl}^{-}\right]$gradient in cultured midbrain neurons provided that appropriate intracellular and extracellular $\mathrm{K}^{+}$and $\mathrm{Cl}^{-}$concentrations are chosen. The somatodendritic gradient is built up by $\left[\mathrm{Cl}^{-}\right]$in the patch pipette solution, which serves as a $\mathrm{Cl}^{-}$source, and the $\mathrm{K}^{+} / \mathrm{Cl}^{-}$cotransporter, which counteracts that $\mathrm{Cl}^{-}$load. This gradient makes it possible to study $\mathrm{Cl}^{-}$regulation through $\mathrm{K}^{+} / \mathrm{Cl}^{-}$cotransport in neurons by measuring differences between somatic and dendritic $E_{\mathrm{GABA}}$. Using this assay, we could identify two groups of neurons in hippocampal cultures on the basis of the respective $\mathrm{GABA}_{\mathrm{A}}$ receptor-mediated synaptic currents generated by the input of spontaneously discharging inhibitory neurons. One group (type 1) comprised mature neurons in which dendritic and somatic sIPSCs could be discriminated by their different driving forces. Immature neurons constituted the second group (type 2) and revealed no difference between dendritic and somatic sIPSCs. Furosemide sensitivity of $E_{\mathrm{GABA}}$ and a difference in somatic and dendritic $E_{\mathrm{GABA}}$ were found only in type 1 neurons. Based on the rank order of potencies of the blockers for KCC2 (Payne, 1997), we conclude that the somatodendritic $\mathrm{Cl}^{-}$gradient is established 

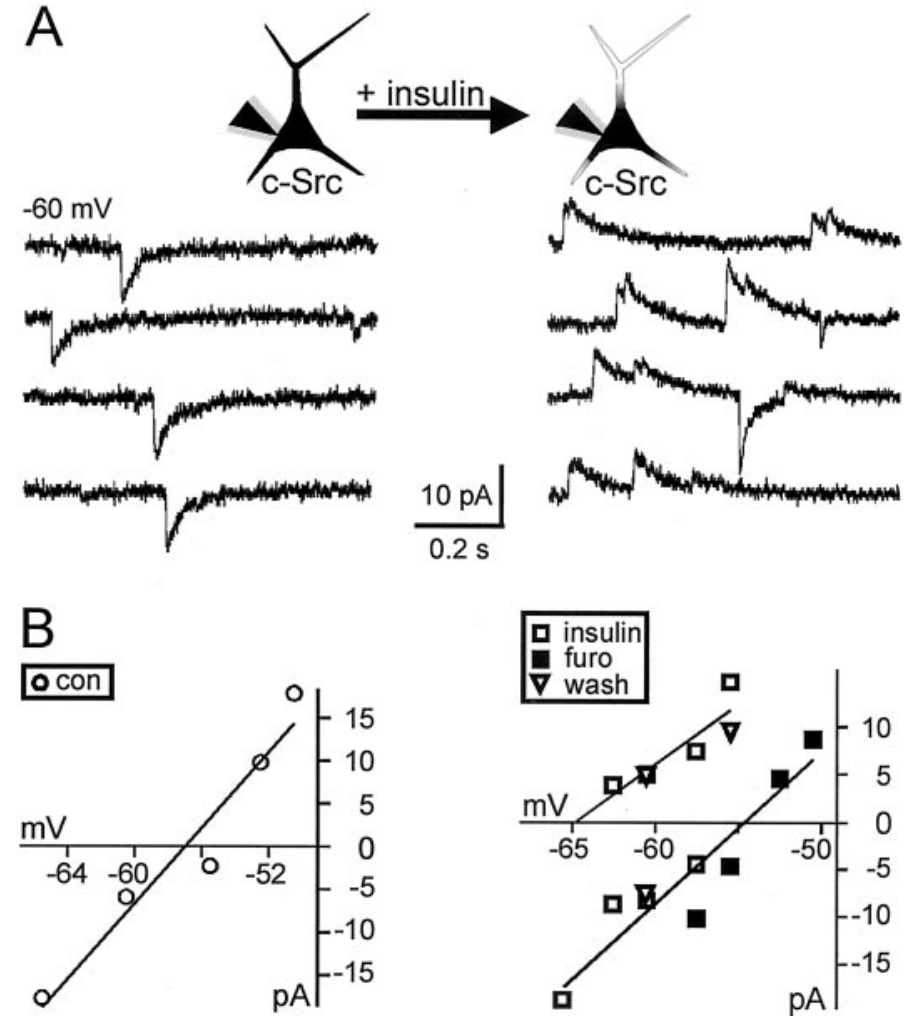

Figure 7. Instantaneous transformation of a type 2 into a type 1 neuron. $A$, Only inward sIPSCs occurred at the indicated $V_{\mathrm{H}}$ during recording with c-Src $(60 \mathrm{U} / \mathrm{ml})$ in the patch pipette solution. After $10 \mathrm{~min}$ of insulin application $(30 \mu \mathrm{g} / \mathrm{ml})$, simultaneous outward and inward currents were recorded at the same $V_{\mathrm{H}}$. $B$, In this neuron, sI PSCs were fitted by a single linear current-voltage relationship. During insulin application, sIPSCs appeared that had to be fitted by a separate line. The change reversed during application of furosemide $(100 \mu \mathrm{M})$, which had been ineffective before insulin application (data not shown). con, Control; furo, furosemide; wash, washout.

by KCC2. Keeping with this notion, our previous study (Jarolimek et al., 1999) showed that the direction of transport is sensitive to small changes of $\left[\mathrm{K}^{+}\right]_{\text {extra }}$, as predicted by the thermodynamic properties of an electroneutral $\mathrm{K}^{+} / \mathrm{Cl}^{-}$cotransport. As expected, there was no interference with voltage-gated $\mathrm{Cl}^{-}$ channels because their influence on the described $\mathrm{Cl}^{-}$homeostasis was very small and could be identified only after a complete blockade of $\mathrm{Cl}^{-}$transport (Smith et al., 1995).

\section{KCC2 function requires tyrosine kinase activity}

$\mathrm{KCC} 2$ is a member of the family of cation-anion cotransporters that regulate cell volume and are essential for salt and water transport across epithelia. To become activated, they are either phosphorylated or dephosphorylated. Abnormalities of erythrocyte $\mathrm{K}^{+} / \mathrm{Cl}^{-}$cotransport in $f g r^{-/-} / h \mathrm{ck}^{-/-}$double-mutant mouse demonstrate that $\mathrm{Src}$ family kinases are involved in the regulation of membrane transport. In this case, the kinases are likely to negatively regulate a cotransporter-activating phosphatase (De Franceschi et al., 1997). Another member of this family, NKCC1, is regulated by protein kinases $\mathrm{A}$ and $\mathrm{C}$, as has been shown for secretory epithelia (for a review of the literature, see Russel, 2000). Neuron-specific KCC2, in contrast to the ubiquitously expressed $\mathrm{KCC} 1$, has a tyrosine kinase consensus site (Payne, 1997). Recently, the inhibitory effect of phosphatase inhibitors demonstrated that serine-threonin phosphorylation events regu- late KCC2 activity in oocytes (Strange et al., 2000). Thus, there are many reasons to believe that phosphorylation could be important in regulating $\mathrm{KCC} 2$ activity.

Genistein and lavendustin A, both membrane-permeable PTK inhibitors, had a furosemide-like effect on the somatodendritic $\mathrm{Cl}^{-}$gradient in mature neurons. The comparable strength of furosemide and genistein indicated that most of the developmental increase in the number of cultured neurons with KCC2 activity was attributable to phosphorylation. In a recent study conducted in Xenopus laevis oocytes, site-directed mutagenesis of exogenously expressed KCC2 (Strange et al., 2000) suggested that the predicted C-terminal tyrosine kinase consensus site of $\mathrm{KCC} 2$ (Payne, 1997) may not be phosphorylated. However, we believe that factors required in neurons for activation of $\mathrm{KCC} 2$ are not present in that artificial expression system because concentrations of genistein twice as high as those used in our study had no effect in the oocytes. A synergistic regulation of the efficacy of inhibitory synapses is suggested by the fact that tyrosine phosphorylation also increases amplitudes of $\mathrm{GABA}_{\mathrm{A}}$ currents (Moss et al., 1995; Wan et al., 1997a). Thus, the phosphorylation step leading to activation of KCC2 may be part of the overall maturation of GABAergic synapses.

\section{Development of KCC2-mediated outward transport of chloride}

We noted an increasing number of cells with transport activity when recording from mature cultures. Maturation of neurons, as determined by the relative amount of type 1 neurons, could be accelerated if cultures were transiently incubated in insulin or in physiological concentrations of IGF-1, suggesting that the effect was mediated by the IGF-1 receptor. Insulin is known to be synthesized by hippocampal neurons (Bartlett et al., 1991) and can be released in a calcium-dependent manner during depolarization (Clarke et al., 1986; Wei et al., 1990). GABAergic stimulation of immature neurons in hippocampal culture leads to a $\mathrm{Ca}^{2+}$ influx, but it reduces the levels of intracellular $\mathrm{Ca}^{2+}$ in mature neurons (Berninger et al., 1995).

Responses to GABA with an elevation of $\left[\mathrm{Ca}^{2+}\right]_{i}$ have been correlated with KCC2 expression in developing hippocampal cultures. A nonlinear relationship between the mRNA of KCC2 and its functional effects was observed. $\mathrm{Ca}^{2+}$ influx during GABA application persisted at a time at which expression of mRNA for KCC2 increased. The transformation of GABA responses could be attributed to a reduced rate of $\mathrm{Cl}^{-}$uptake as a result of decreasing $\mathrm{NKCC1}$ activity, as well as to increasing KCC2 activity (Ganguly et al., 2001). Other factors to consider when monitoring $\mathrm{Ca}^{2+}$ influx are developmental changes in the kinetics of $\mathrm{Ca}^{2+}$ current activation attributable to a reduced expression of L-type channels (Pravettoni et al., 2000) and increases in resting membrane potentials. Because KCC2 protein was abundant and because comparable amounts of mRNA for KCC2 were present both in insulin-treated and untreated cultures, we concluded that the presence of KCC2 protein alone is not sufficient to induce transport activity. Assuming that tyrosine kinase phosphorylation provides the key to activate $\mathrm{KCC} 2$, we applied insulin or IGF-1 in conjunction with intracellular perfusion of c-Src protein and found that the transport was rapidly activated. Perfusion with c-Src alone was not sufficient for activation of the transport, excluding the possibility that c-Src mediated the entire response to IGF-1. Our data, however, do not provide direct evidence for upregulation of tyrosine kinase during chronic insulin exposure. Also, an upregulation of other 
KCCs, which may contribute to net $\mathrm{Cl}^{-}$outward transport, was not excluded.

IGF-1 is known to rapidly activate calcium channels by phosphorylation of a subunit via a cytosolic PTK (Bence-Hanulec et al., 2000). An alternative mechanism can be inferred from studies demonstrating that insulin-induced potentiation of NMDA receptor activity does not result from direct phosphorylation of the receptor but from phosphorylation of associated C-terminal tails of anchoring or signaling proteins (Skeberdis et al., 2001). Insulin is also known to potentiate $\mathrm{GABA}_{\mathrm{A}}$ receptor currents by recruitment of functional $\mathrm{GABA}_{\mathrm{A}}$ receptors to postsynaptic CA1 synapses (Wan et al., 1997b). However, because high concentrations of insulin were necessary to potentiate the $\mathrm{GABA}_{\mathrm{A}}$ receptor in that study, it is likely that the effect was mediated via interaction with the IGF-1 receptor that is expressed at high levels in the developing and adult hippocampus (Kar et al., 1993). Interestingly v-Src kinase has been shown to phosphorylate and activate IGF-1 receptors (Peterson et al., 1996). Therefore, endogenous c-Src, once activated, might act via both direct and indirect mechanisms, creating a positive feedback cycle to drive the phosphorylation mechanism mediating KCC2 activity to higher levels.

In conclusion, the rapid activation of $\mathrm{KCC} 2$-mediated transport by IGF-1-insulin and c-Src in cultured neurons indicates that development of neuronal $\mathrm{K}^{+} / \mathrm{Cl}^{-}$cotransport requires cooperation of a growth factor with PTK-dependent phosphorylation. In this regard, KCC2 is similar to ionotropic receptors and other ion channels whose function is also regulated by PTK-dependent phosphorylation. Transcriptional mechanisms, although known to regulate $\mathrm{KCC} 2$ levels in the brain, are not sufficient for the induction of $\mathrm{KCC} 2$ activity, at least in cultured neurons. Our studies show that tyrosine phosphorylation is important for rapidly regulating a transport in neurons, which determines the efficacy of postsynaptic inhibition. What may the role of phosphorylation of KCC2 throughout postnatal life be? The very fast and almost complete effect of PTK inhibitors suggested a high turnover rate of phosphorylation and dephosphorylation. In concert with the regulation of $\mathrm{GABA}_{\mathrm{A}}$ receptors by Src family kinases, fast regulation of KCC2 activity and, hence, postsynaptic inhibition may be important for synaptic plasticity and network excitability. Furthermore, protein tyrosine phosphorylation has been implicated in modifications of neuronal function in pathological conditions such as epilepsy (Sanna et al., 2000). A reduction of KCC2-mediated transport by furosemide promotes epileptiform activity in neuronal networks (Jarolimek et al., 1996), whereas activation of the transport might counteract an excessive enhancement of NMDA receptor-dependent excitatory transmission induced by c-Src (Yu and Salter, 1999). Given the prominent role of synaptic inhibition in mediating many brain functions and dysfunctions, modulation of KCC2 activity by PTKs may be important in a wide range of physiological and pathological processes in the CNS.

\section{REFERENCES}

Akiyama T, Ishida J, Nakagawa S, Ogawara H, Watanabe S, Itoh N, Shibuya M, Fukami Y (1987) Genistein, a specific inhibitor of tyrosine-specific protein kinase. J Biol Chem 262:5592-5595.

Bartlett WP, Li XS, Williams M, Benkovic S (1991) Localization of insulin-like growth factor-1 mRNA in murine central nervous system during postnatal development. Dev Biol 147:239-250.

Ben-Ari Y, Cherubini E, Corradetti R, Gaiarsa J-L (1989) Giant synaptic potentials in immature rat CA3 hippocampal neurones. J Physiol (Lond) 416:303-325.

Bence-Hanulec KK, Marshall J, Blair LAC (2000) Potentiation of neuronal L calcium channels by IGF-1 requires phosphorylation of the $\alpha 1$ subunit on a specific tyrosine residue. Neuron 27:121-131.
Berninger B, Marty S, Zafra F, da Penha Berzaghi M, Thoenen H, Lindholm D (1995) GABAergic stimulation switches from enhancing to repressing BDNF expression in rat hippocampal neurons during maturation in vitro. Development 121:2327-2335.

Capogna M, Gähwiler BH, Thompson SM (1995) Presynaptic enhancement of inhibitory synaptic transmission by protein kinases $\mathrm{A}$ and $\mathrm{C}$ in the rat hippocampus in vitro. J Neurosci 15:1249-1260.

Catarsi S, Drapeau P (1993) Tyrosine kinase-dependent selection of transmitter responses induced by neuronal contact. Nature 363:353-355.

Cherubini E, Gaiarsa JL, Ben-Ari Y (1991) GABA: an excitatory transmitter in early postnatal life. Trends Neurosci 14:515-519.

Clarke DW, Mudd L, Boyd Jr FT, Fields M, Raizada MK (1986) Insulin is released from rat brain neuronal cells in culture. J Neurochem 47:831-836.

Clayton GH, Owens GC, Wolff JS, Smith RL (1998) Ontogeny of cation$\mathrm{Cl}^{-}$cotransporter in rat neocortex. Dev Brain Res 109:281-292.

De Franceschi L, Fumagalli L, Olivieri O, Corrocher R, Lowell CA, Berton G (1997) Deficiency of Src family kinases Fgr and Hck results in activation of erythrocyte K-Cl-cotransport. J Clin Invest 99:220-227.

DeFazio RA, Keros S, Quick MW, Hablitz JJ (2000) Potassium-coupled chloride cotransport controls intracellular chloride in rat neocortical pyramidal neurons. J Neurosci 20:8069-8076.

Ehrlich I, Löhrke S, Friauf E (1999) Shift from depolarizing to hyperpolarizing glycine action in rat auditory neurones is due to agedependent $\mathrm{Cl}^{-}$regulation. J Physiol (Lond) 520:121-137.

Ganguly K, Schinder AF, Wong ST, Poo M (2001) GABA itself promotes the developmental switch of neuronal GABAergic responses from excitation to inhibition. Cell 105:521-532.

Hübner CA, Stein V, Hermans-Borgmeyer I, Meyer T, Ballanyi K, Jentsch TJ (2001) Disruption of KCC2 reveals an essential role of $\mathrm{K}-\mathrm{Cl}$ cotransport already in early postsynaptic inhibition. Neuron 30:515-524.

Jarolimek W, Misgeld U (1992) On the inhibitory actions of baclofen and $\gamma$-aminobutyric acid in rat ventral midbrain culture. J Physiol (Lond) 451:419-443.

Jarolimek W, Misgeld U (1997) GABA $_{B}$ receptor-mediated inhibition of tetrodotoxin-resistant GABA release in rodent hippocampal CA1 pyramidal cells. J Neurosci 17:1025-1032.

Jarolimek W, Brunner H, Lewen A, Misgeld U (1996) Role of chloridehomeostasis in the inhibitory control of neuronal network oscillators. J Neurophysiol 75:2654-2657.

Jarolimek W, Lewen A, Misgeld U (1999) A furosemide-sensitive $\mathrm{K}^{+}$$\mathrm{Cl}^{-}$cotransporter counteracts intracellular $\mathrm{Cl}^{-}$accumulation and depletion in cultured rat midbrain neurons. J Neurosci 19:4695-4704.

Kaila K, Voipio J, Pasternack M, Paalasmaa P, Deisz RA (1993) The role of bicarbonate in $\mathrm{GABA}_{\mathrm{A}}$ receptor-mediated IPSPs in rat neocortical neurons. J Physiol (Lond) 464:273-289.

Kakazu Y, Akaike N, Komiyama S, Nabekura J (1999) Regulation of intracellular chloride by cotransporters in lateral superior olive neurons. J Neurosci 19:2843-2851.

Kar S, Chabot JG, Quirion R (1993) Quantitative autoradiographic localization of $\left[{ }^{125} \mathrm{I}\right]$ insulin-like growth factor I, $\left.{ }^{125} \mathrm{I}\right]$ insulin-like growth factor II, and $\left[{ }^{125} \mathrm{I}\right]$ insulin receptor binding sites in developing and adult rat brain. J Comp Neurol 333:375-397.

Lu J, Karadsheh M, Delpire E (1999) Developmental regulation of the neuronal-specific isoform of $\mathrm{K}-\mathrm{Cl}$ cotransporter $\mathrm{KCC} 2$ in postnatal rat brain. J Neurobiol 39:558-568.

Misgeld U, Deisz RA, Dodt HU, Lux HD (1986) The role of chloride transport in postsynaptic inhibition of hippocampal neurons. Science 232:1413-1415.

Moshnyakov M, Arumae U, Saarma M (1996) mRNAS for one, two or three members of trk receptor family are expressed in single rat trigeminal ganglion neurons. Brain Res Mol Brain Res 43:141-148.

Moss SJ, Gorrie GH, Amato A, Smart TG (1995) Modulation of GABA $_{\mathrm{A}}$ receptors by tyrosine phosphorylation. Nature 377:344-348.

O'Dell TJ, Kandel ER, Grant SGN (1991) Long-term potentiation in the hippocampus is blocked by tyrosine kinase inhibitors. Nature 353:558-560.

Payne JA (1997) Functional characterization of the neuronal-specific $\mathrm{K}-\mathrm{Cl}$ cotransporter: implications for $\left[\mathrm{K}^{+}\right]_{\mathrm{o}}$ regulation. Am J Physiol Cell Physiol 273:C1516-C1525.

Payne JA, Stevenson TJ, Donaldson LF (1996) Molecular characterization of a putative K-Cl cotransporter in rat brain. A neuronal-specific isoform. J Biol Chem 271:16245-16252.

Peterson JE, Kulik G, Jelinek T, Reuter CW, Shannon JA, Weber MJ (1996) Src phosphorylates the insulin-like growth factor type I receptor on the autophosphorylation sites. Requirement for transformation by Src. J Biol Chem 271:31562-31571.

Pravettoni E, Bacci A, Coco S, Forbicini P, Matteoli M, Verderio C (2000) Different localizations and functions of L-type and N-type calcium channels during development of hippocampal neurons. Dev Biol 227:581-594.

Rivera C, Voipio J, Payne JA, Ruusuvuori E, Lahtinen H, Lamsa K, Pirvola U, Saarma M, Kaila K (1999) The $\mathrm{K}^{+} / \mathrm{Cl}^{-}$cotransporter 
KCC2 renders GABA hyperpolarizing during neuronal maturation. Nature 397:251-255.

Russel JM (2000) Sodium-potassium-chloride cotransport. Physiol Rev 80:211-276.

Sanna PP, Berton F, Cammalleri M, Tallent MK, Siggins GR, Bloom FE, Francesconi W (2000) A role for Src kinase in spontaneous epileptic activity in the CA3 region of the hippocampus. Proc Natl Acad Sci USA 97:8653-8657.

Skeberdis VA, Lan J, Zheng X, Zukin RS, Bennett MVL (2001) Insulin promotes rapid delivery of $N$-methyl-D-aspartate receptors to the cell surface by exocytosis. Proc Natl Acad Sci USA 98:3561-3566.

Smith RL, Clayton GH, Wilcox CL, Escudero KW, Staley KJ (1995) Differential expression of an inwardly rectifying chloride conductance in rat brain neurons: a potential mechanism for cell-specific modulation of postsynaptic inhibition. J Neurosci 15:4057-4067.

Strange K, Singer TD, Morrison R, Delpire E (2000) Dependence of $\mathrm{KCC} 2 \mathrm{~K}-\mathrm{Cl}$ cotransporter activity on a conserved carboxy terminus tyrosine residue. Am J Physiol Cell Physiol 279:C860-C867.
Thompson SM, Deisz RA, Prince DA (1988) Outward chloride/cation cotransport in mammalian cortical neurons. Neurosci Lett 89:49-54.

Wan Q, Man HY, Braunton J, Wang W, Salter MW, Becker L, Wang YT (1997a) Modulation of GABA receptor function by tyrosine phosphorylation of $\beta$ subunits. J Neurosci 17:5062-5069.

Wan Q, Xiong Z-G, Man HY, Ackerley CA, Braunton J, Lu WY, Becker LE, Macdonald JF, Wang YT (1997b) Recruitment of functional $\mathrm{GABA}_{\mathrm{A}}$ receptors to postsynaptic domains by insulin. Nature 388:686-690

Wei LT, Matsumoto H, Rhoads DE (1990) Release of immunoreactive insulin from rat brain synaptosomes under depolarizing conditions. J Neurochem 54:1661-1665.

Williams JR, Sharp JW, Kumari VG, Wilson M, Payne JA (1999) The neuron-specific $\mathrm{K}-\mathrm{Cl}$ cotransporter, KCC2. Antibody development and initial characterization of the protein. J Biol Chem 274:12656-12664.

Yu X-U, Salter MW (1999) Src, a molecular switch governing gain control of synaptic transmission mediated by $N$-methyl-D-aspartate receptors. Proc Natl Acad Sci USA 96:7697-7704. 